\title{
ARTYKUtY
}

Klio. Czasopismo poświęcone dziejom Polski i powszechnym

PL ISSN 1643-8191, t. 41 (2)/2017, s. 7-30

(1) $\odot$

http://dx.doi.org/10.12775/KLIO.2017.026

DAgmara AdAMSKA ${ }^{*}$

\section{Domy szlacheckie w późnośredniowiecznym i uczesnonowożytnym Głogowie}

\section{Houses of the nobility in the late-medieval and early modern Głogów}

Streszczenie: Artykuł podejmuje zagadnienie obecności szlachty w Głogowie (Śląsk) w XV-XVI wieku. Jego celem jest wskazanie liczby domów, ich lokalizacji, zrekonstruowanie losów obiektów, aby przybliżyć przyczyny utrzymywania przez szlachtę posesji w Głogowie. Wskazano trzy skupiska dworów. Większość domów znajdowała się na „zamkowym lennie" - w sąsiedztwie murów miejskich i zamku. Dwa domy możemy wskazać poza murami miejskimi na Ostrowie Tumskim; dwa - w sąsiedztwie posesji mieszczańskich, ale w prestiżowej części miasta, gdzie znajdowała się też parcela biskupa i klasztory. Metryka dworów nie jest jasna. Poznajemy je w połowie XV wieku, za panowania w Głogowie książąt cieszyńskich - Włodka i Małgorzaty. Utrzymywanie przez szlachciców miejskich posesji w większości wypadków koreluje z pełnieniem przez nich funkcji dworskich i urzędniczych, ale jednocześnie z posiadaniem majątków wiejskich. Dwory na

* Instytut Historyczny Uniwersytetu Wrocławskiego, ul. Szewska 49, 50-139 Wrocław, dagaad@wp.pl. 
„zamkowym lennie” mogły pełnić rolę domów noclegowych, ale i dawać ich posiadaczom możliwość realizacji interesów gospodarczych. W przypadku nieruchomości na Ostrowie Tumskim hipoteza o stałej obecności szlachciców w mieście wydaje się prawdopodobniejsza.

Abstract: The article deals with the presence of the nobility in Głogów (Silesia) in the 15th and 16th centuries. It aims at indicating the number of houses, their locations, as well as reconstructing the fate of the objects, in order to bring closer the reasons for keeping up properties by the gentry in Głogów. Three clusters of manor houses were indicated. Most of the houses were on the "castle fief" (Burglehn), in the neighborhood of city walls and the castle. Two houses can be located outside the city walls on Ostrów Tumski; and the other two in the neighborhood of the bourgeois properties, but in the prestigious part of the city, including also the bishop's parish and monasteries. The public registers of the manor houses are not clear. We find out about them in the middle of the 15th century, during the reign of Cieszyn dukes in Głogów - Włodek and Margaret. Maintaining city property by the nobles in most cases correlates with the performance of their court and clerical functions, but also with the possession of rural estates. Manor houses on the "castle fiefs" could be used for accommodation, but also give the owners the opportunity for the enforcement of interests. In the case of properties on Ostrów Tumski, the hypothesis of a stable presence of noblemen in the city seems to be more likely.

Słowa kluczowe: szlachta, domy szlacheckie, Głogów, Śląsk

Keywords: nobility, houses of the nobility, Głogów, Silesia

\section{7 agadnienie obecności rycerstwa ${ }^{1}$ w śląskich miastach nie cieszy się dostatecznym zainteresowaniem badaczy. Tym samym istnieje rozdź- więk między stanem wiedzy na temat Śląska a pozostałych ziem Polski².}

${ }^{1}$ Dla późnego średniowiecza - szlachty.

${ }^{2}$ Zob.: J. Wiesiołowski, Szlachta w mieście. Przemieszczenia i migracje szlachty między wsia a miastem $w$ Polsce $X V w$., „Studia i Materiały do Dziejów Wielkopolski i Pomorza” 14, 1980, 1, s. 47-75 (tam starsza literatura), z nowszej: idem, Socjotopografia późnośredniowiecznego Poznania, Warszawa-Poznań 1982; U. Sowina, Sieradz. Uktad przestrzenny $i$ spoteczeństwo miasta $w$ XV-XVI w., Warszawa-Sieradz 1991; R. Czaja, Socjotopografia Elblaga w średniowieczu, Toruń 1992; P. Węcowski, Dziatalność publiczna możnowtadztwa matopolskiego w późnym średniowieczu, Warszawa 1998; K. Mikulski, Przestrzeń i spoteczeństwo Torunia od końca XIV do początku XVIII wieku, Toruń 1999; T. Stolarczyk, Szlachta wieluniska od XIV do potowy XVI wieku, Wieluń 2005. 
Właściwie można wskazać jedynie kilka prac, choć tutejsze badania mają już długą tradycję ${ }^{3}$. Studium socjotopograficznego, w którym podjęto także interesującą nas kwestię nieruchomości, doczekały się dwa miasta: Wrocław i Świdnica ${ }^{4}$. Ostatnie badania Agnieszki Malczewskiej zaowocowały ustaleniami dla kilku kolejnych ośrodków (Brzeg, Strzelin, Ziębice, Ząbkowice oraz Kłodzko), choć - jak sama autorka przyznaje - nie pretendują one do roli „pełnego przedstawienia problematyki rycerstwa w [tychże] miastach”.

Istnienie szlacheckich posesji w Głogowie zauważyli tylko nieliczni badacze. Pierwszym był bodajże Ferdinand Minsberg, autor dziewiętnastowiecznej monografii miasta. Zainteresował go jednak tylko jeden dom (tzw. Tschmmerhof) i to jego status próbował wyjaśnićc. Wnikliwe studium średniowiecznego rozplanowania Głogowa wyszło spod pióra historyka sztuki - Mariana Kutznera. Zagadnieniu szlacheckich domów poświęcił on jednak niewiele miejsca; wskazał dwa i zaproponował ich lokalizację.

${ }^{3}$ G. Pfeiffer, Das mittelalterliche Patriziat der Stadt Breslau (Darstellungen und Quellen zur schlesische Geschichte 30) Breslau 1929, s. 186-224; H.J. WitzendorffRehdiger, Der ritterliche Adel und der Stadtadel in Schlesien, „Jahrbuch der Schlesischen Friedrich-Wilhelms Universität zu Breslau” 1961, H. 6, s. 193-212.

${ }^{4}$ M. Goliński, Socjotopografia średniowiecznego Wroctawia, Wrocław 1997, s. 108 -109, 127-129, 242; idem, Rycerstwo w mieście na przyktadzie Świdnicy w 2. pot. XIV w. Problem przyczyn i charakteru obecności oraz lokalizacja w miejskiej przestrzeni, [w:] Sociálni svět středověkého mèsta, red. M. Nodl (Colloquia mediaevalia Pragensia 5) Praga 2006, s. 165-172; idem, Wokót socjotopografii późnośredniowiecznej Świdnicy, cz. 1, Wrocław 2000, s. 106; idem, Wokót socjotopografii późnośredniowiecznej Świdnicy, cz. 2, Wrocław 2003, s. 136-152; zob. też: idem, Ulice późnośredniowiecznego Wroctawia w świetle źródet pisanych, [w:] Ulice średniowiecznego Wroctawia, red. J. Piekalski, K. Wachowski (Wratislavia Antiqua 11), Wrocław 2010, s. 57-66.

${ }^{5}$ A. Malczewska, Posesjonaci szlacheccy w wybranych miastach późnośredniowiecznego i wczesnonowożytnego Ślaska (w Brzegu, Strzelinie, Ziębicach, Ząbkowicach Śląsich i Ktodzku), [w:] Miasto jako fenomen spoteczny i kulturowy. Zbiór studiów, red. C. Kardasz, J. Możdżeń, M. Spychaj, Toruń 2011, s. 123 (107-123); eadem, Posesjonaci z rodu von Haugwitz w późnośredniowiecznym Ktodzku - przyczynek do badań nad rycerstwem w miastach XIV-i XV-wiecznego Ślaska, [w:] Rody na Ślasku, Rusi Czerwonej i w Matopolsce: średniowiecze i czasy nowożytne. Stan badań, metodologia, nowe ustalenia, red. W. Zawitkowska, A. Pobóg-Lenartowicz, Rzeszów 2010, s. 206-217.

6 F. Minsberg, Geschichte der Stadt und Festung Groß-Glogau, Bd. 2, Glogau 1853, s. 118, a za nim: J. Blaschke, Geschichte der Stadt Glogau und des Glogauer Landes, Glogau 1913 , s. 165. 
Zasugerował też genezę Tschammerhofu, do czego jeszcze powrócimy ${ }^{7}$. Ten sam dwór zainteresował ostatnio Petra Kozáka, który naświetlił jego status i okoliczności pozyskania przez Tschammerów ${ }^{8}$. W tym samym czasie tematykę siedzib podjął Dominik Nowakowski. Ponieważ jednak synteza ta dotyczy głównie zamków rozpoznanych archeologicznie, autor ograniczył się do wyliczenia posesji w miastach księstwa głogowskiego, choć w większości nieznanych literaturze przedmiotu?

O domach w Głogowie pisało już zatem kilku badaczy, ale nadal pozostaje niewyjaśnionych wiele kwestii. Pomimo niezadowalającej podstawy źródłowej ${ }^{10}$ warto przyjrzeć się im dokładniej, choć dane o szlacheckich dworach to właściwie małe fragmenty, które z trudem dają się ułożyć w spójny obraz. Jego zadaniem - w założeniu - było ukazanie liczby domów, ich lokalizacji w miejskiej przestrzeni oraz zrekonstruowanie losów poszczególnych obiektów. Ustalenia te miały z kolei przybliżyć do poznania przyczyny utrzymywania przez szlachtę posesji w Głogowie. Funkcje i metryka nieruchomości z racji ułomnej podstawy źródłowej musiały jednak zostać potraktowane marginalnie. Wyniki badań nie pozwoliły bowiem przesądzić o charakterze obecności szlachty w mieście (periodycznej lub stałej) ${ }^{11}$.

Zebrane dane ukazały, że w przypadku Głogowa mamy do czynienia z trzema skupiskami dworów: na obszarze przynależącym do tzw. lenna

${ }^{7}$ M. Kutzner, Gtogów, [w:] Studia nad początkami i rozplanowaniem miast nad środkowa Odra i Dolną Wartą, t. 2, red. Z. Kaczmarczyk, A. Wędzki, Zielona Góra 1970, s. 167, 204, il. 22.

${ }^{8}$ P. Kozák, Zrod stavovského Hlohovska. Mocenská uskupeni ve Slezském pozdním středověku, Opava 2008, s. 111-112.

9 D. Nowakowski, Siedziby książęce i rycerskie księstwa gtogowskiego w średniowieczu, Wrocław 2008, s. 121-126.

10 Stan zachowania spuścizny władz municypalnych Głogowa skazuje na korzystanie z dawnych inwentarzy miejskich archiwów: Die Inventare der nichtstaatlichen Archive Schlesiens. Die Kreise Grünberg und Freystadt, ed. K. Wutke, Codex Diplomaticus Silesiae (dalej: CDS), Bd. 24, Breslau 1908; Die Inventare der nichtstaatlichen Archive Schlesiens. Kreis und Stadt Glogau, ed. K. Wutke, CDS, Bd. 28, Breslau 1915.

${ }^{11}$ J. Wiesiołowski, Socjotopografia późnośredniowiecznego Poznania, s. 123. Autor podzielił poznańskie domy na noclegowe dla urzędników oraz starsze - rezydencjonalne. 
zamkowego ${ }^{12}$; w północnym, nadrzecznym pasie miasta oraz poza murami, w sąsiedztwie kamiennej drogi ${ }^{13}$. Jako wyjątkowy postrzegam dom Andrzeja von Berge, który w połowie XV wieku stał nieopodal fary.

\section{Głogouskie „lenno zamkowe”}

Książęcy obszar związany z zamkiem miał zostać wydzielony w północnej i zachodniej części Głogowa. Ten zarezerwowany przez władcę kwartał odpowiadał terenowi objętemu jego jurysdykcja, wyznaczonemu przy wytyczaniu miasta ${ }^{14}$. W Głogowie pokrywał się on rzekomo z zasięgiem jednego z przedlokacyjnych osiedli, które zostało zlikwidowane (do 1253 roku) wraz z reorganizacją policentrycznego zespołu osadniczego położonego przy przeprawie przez Odrę ${ }^{15}$. Książęcy zamek stanął

12 Terminu „lenno zamkowe” używam w odniesieniu do obszaru przynależnego do tegoż lenna, co zgodne jest z językiem przywoływanych źródeł.

${ }^{13}$ Parcele położone poza tradycyjnymi osiedlami patrycjuszowskimi, tj. przy zamku, na obrzeżu miast, wskazują: J. Wiesiołowski, Socjotopografia późnośredniowiecznego Poznania, s. 123; P. Węchowski, op. cit. O zbliżonej topografii w Świdnicy: M. Goliński, Rycerstwo w mieście, s. 167; idem, Wokótsocjotopografii, cz. 2, s. 141; w Brzegu i Ząbkowicach: A. Malczewska, Posesjonaci szlacheccy, s. 114-115, 120. W Żaganiu domy zlokalizowane były obok klasztoru Augustianów i na „zamkowym lennie”, wzdłuż Edelgasse: G. Steller, Grund- und Gutsherren im Fürstentum Sagan 1400-1940, Sagan 1940, s. 137-138; D. Nowakowski, op. cit., s. 122; w Strzegomiu - przy ul. Zakonnej i Świdnickiej, od strony miejskich murów: Strzegomska księga podatkowa z 1528 roku, wyd. D. Adamska, M. Goliński, [w:] Z kancelarii XVI-wiecznych miast śląskich. Edycje źródet ze Strzegomia, Świdnicy $i$ Wroctawia, red. M. Goliński, Łódź-Wrocław 2016, nr 65, s. 225; w niewielkim Strzelinie - wzdłuż Rittergasse, tj. przy murach, na „zamkowym lennie”, a pojedyncze przy Rynku: F.X. Görlich, Geschichte der Stadt Strehlen in Preußisch Schlesien, Breslau 1853, s. 385-386 oraz A. Malczewska, Posesjonaci szlacheccy, s. 117. Przy obecnym stanie badań domy poza murami znane są tylko z Żagania i Kożuchowa: D. Nowakowski, op. cit., s. $122-124$.

${ }^{14}$ M. Kutzner, op. cit., s. 166-167.

15 T. Kozaczewski, Gtogów średniowieczny do końca XIII w., Głogów 2006, s. 140; zob. wątpliwości M. Golińskiego w sprawie zakładanej przez M. Kutznera (op. cit., s. 155) równoznaczności między mieszkańcami starszej osady a lokacyjnej gminy: Wokót problematyki formowania się stanu mieszczańskiego w Polsce, [w:] Studia z historii spotecznej, red. M. Goliński, S. Rosik (Scripta Historica Medievalia 2), Wrocław 2012, s. 25-26. 
na wysokim brzegu Odry, w północno-zachodnim narożniku miasta (ryc. $1 \mathrm{~A})^{16}$.

Najstarsze elementy pozwalają datować siedzibę na połowę XIII wie$\mathrm{ku}$, choć zasadnicza rozbudowa została podjęta na przełomie XIII i XIV stulecia $^{17}$. W świetle źródeł pisanych po raz pierwszy wymieniono warownię (castrum) w 1296 roku $^{18}$. Nową parcelę na obszarze książęcego kwartału otrzymali dominikanie pod budowę klasztoru (1258 rok). Na potrzeby zakonników wyznaczono teren położony na północ od świątyni pw. św. Piotra i Pawła, gdyż ten dotychczas użytkowany wydawał im się suchy ${ }^{19}$ (ryc. 1.6). W XV wieku obok dominikanów mieszkały ubogie siostry, których siedzibę odczytuje się jako beginaż, choć raczej był to „dom duszny” ${ }^{20}$. Od połowy stulecia wymieniano też przyklasztorny cmentarz, obok którego stał szpital ${ }^{21}$. Przynajmniej od 1299 roku pod

Zespół osadniczy składał się z grodu na Ostrowie Tumskim z kościołem NMP, dwóch lewobrzeżnych osad oraz jednej prawobrzeżnej. Jedynie pojedyncze znaleziska ceramiki stalowoszarej przesądzają o kresie funkcjonowania osiedli w poł. XIII w. Na skraju wyspy położona była też osada rybacka. Regesten zur schlesischen Geschichte (dalej: RS), CDS, Bd. 22, ed. C. Grünhagen, K. Wutke, Breslau 1903, nr 5247; Kaspar Borgeni, Rocznik gtogowski do roku 1493, wyd. W. Mrozowicz, Głogów 2013 (dalej: RG), s. 120; F. Minsberg, op. cit., s. 165-166; M. Kutzner, op. cit., passim; Cz. Lasota, Wyniki dotychczasowych badań nad osadnictwem przedlokacyjnego lewobrzeżnego Gtogowa, „Prace Naukowe Instytutu Historii Architektury, Sztuki i Techniki” 2, 1972, s. 73-85; M. Słoń, Miasta podwójne i wielokrotne w średniowiecznej Europie, Wrocław 2010, s. 172; zob. też: Handbuch der historischen Stätten. Schlesien, ed. H. Weczerka, Stuttgart 1977, s. 127-128; T. Jurek, Konrad I. gtogowski. Studium z dziejów dzielnicowego Slaska, „Roczniki Historyczne” 54, 1988 , s. $115-116$.

${ }^{16}$ Starszy zamek stał na niewielkim wyniesieniu na Ostrowie Tumskim i już w 1307 r. określany był jako alte Schloss: RS, CDS, Bd. 16, ed. C. Grünhagen, K. Wutke, Breslau 1892, nr 2939; D. Nowakowski, op. cit., s. 330-335.

${ }^{17}$ D. Nowakowski, op. cit., s. 335-340.

${ }_{18}$ Schlesisches Urkundenbuch (dalej: SUb), Bd. 6, ed. W. Irgang, Köln-Weimar-Wien 1998, nr 272.

${ }^{19}$ Ibidem, Bd. 3, ed. W. Irgang, Köln-Wien 1984, nr 260. Informacja o „suchej ziemi” może pośrednio wskazywać na przyczynę słabego zachowania drewna w Głogowie i tym samym usprawiedliwić brak badań dendrochronologicznych.

${ }^{20}$ CDS, Bd. 28, s. 70; J. Szymański, Ruchy heretyckie na Ślasku w XIII i XIV wieku, Chudów 2007, s. 95.

${ }^{21}$ CDS, Bd. 28, s. 107, 111, 138, 149. 


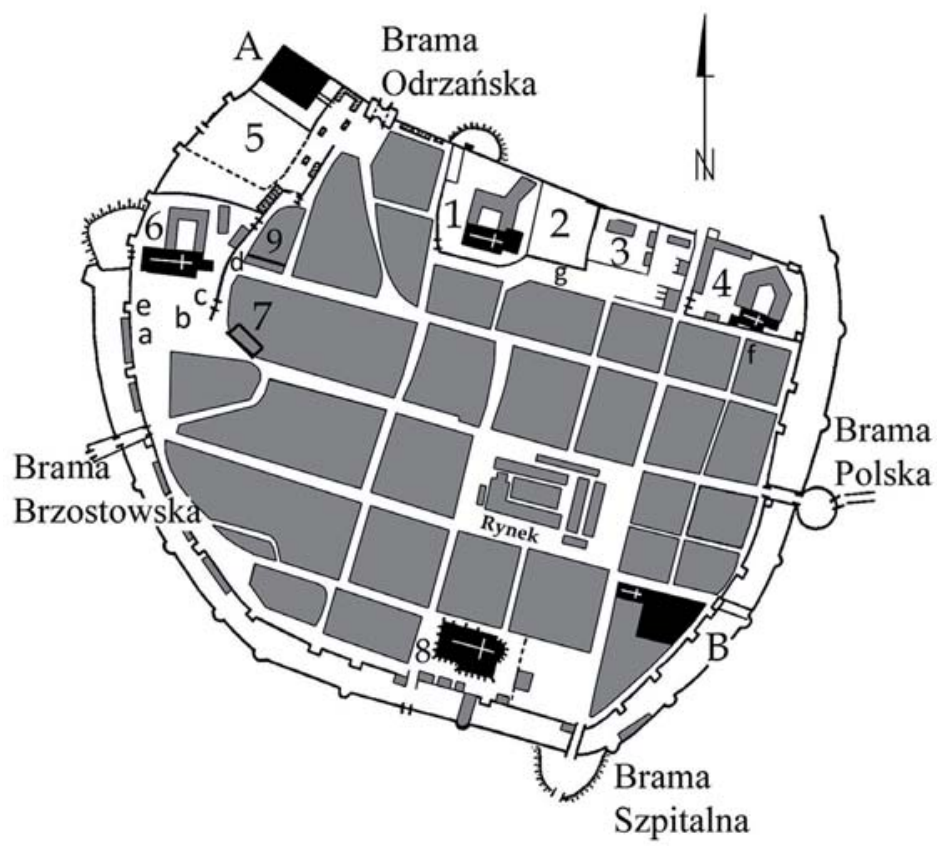

Ryc. 1. Domniemany zasięg jurydyki książęcej

Plan sytuacyjny średniowiecznego Głogowa w obrębie murów miejskich (rys. aut. z wykorzystaniem W. Klawitter, op. cit., il. 3): A - zamek (starszy); B - zamek (młodszy); 1 - klasztor i kościół franciszkanów; 2 - ogród franciszkanów; 3 - dwór biskupa; 4 - klasztor i kościół klarysek; 5 - ogród zamkowy; 6 - klasztor i kościół dominikanów; 7 - łaźnia wójtowska; 8 - fara św. Mikołaja; 9 - młyn koński i starsze osiedle żydowskie. Domniemana i przybliżona lokalizacja domów rycerskich: a - Tschammerhof; b - dom Tschammerów; c - dom Rechenbergów; d - dom Rechenbergów na Rossmühle; e - dom Wandritschów / szpital; f - dom Kottwitzów.

Źródło: opracowanie autorki

zamkiem mieszkali Żydzi. Należące do nich posesje i synagoga znajdowały się wzdłuż Judengasse - „w przyjętych od dawna granicach”22 (ryc. 1.9). W północnej części rezerwy księcia, w sąsiedztwie wysokiego nabrzeża,

${ }^{22}$ Ibidem, s. 81-83; RG, s. 110. Średniowieczny cmentarz znajdował się prawdopodobnie kilkanaście kilometrów od miasta: D. Adamska, W sprawie lokalizacji żydowskich cmentarzy na średniowiecznym Śląsku (artykuł w druku). 
stanął murowany kościół pw. św. Stanisława wraz z klasztorem Franciszkanów (po 1253 roku) ${ }^{23}$ (ryc. 1.1). Opodal niego ufundowano (w latach 1304-1307) elitarną placówkę klarysek. W skład tego kompleksu wchodził kościół pw. Świętego Krzyża, budynki klasztorne oraz szpital ${ }^{24}$ (ryc. 1.4). W 1399 roku w sąsiedztwie Ubogich Panien wzmiankowano dwór biskupa, który zajmował parcelę przyległą do ogrodu franciszkanów ${ }^{25}$ (ryc. 1.3; 2). Prawdopodobnie już poza granicą książęcego kwartału można zobaczyć wójtowską łaźnię (ryc. 1.7) oraz parcelę sołtysa z Kotli ${ }^{26}$.

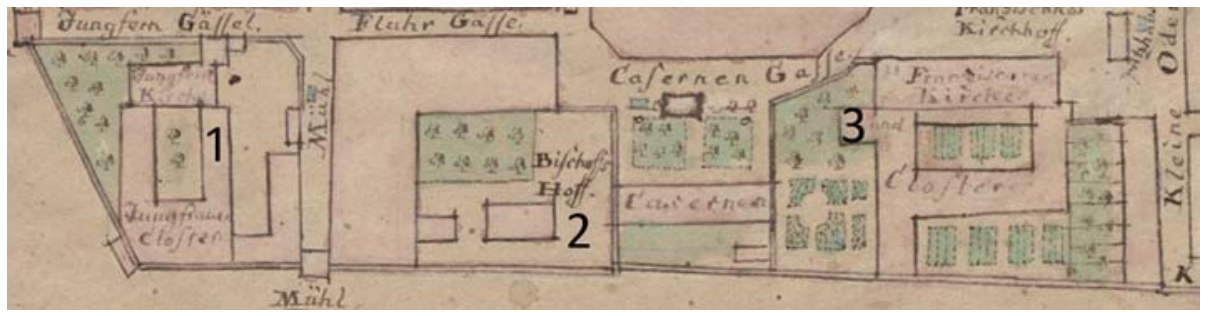

Ryc. 2. Fragment północnej jurydyki książęcej

1 - kościół i klasztor klarysek; 2 - parcela biskupia; 3 - kościół, klasztor i ogród franciszkanów.

Źródło: Grund-Riss der Stadt Gros Glogau ohne den Dom, 1785, zbiory prywatne, domena publiczna.

23 SUb, Bd. 3, nr 353; M. Kutzner, op. cit., s. 167.

${ }^{24}$ RS, CDS, Bd. 16, nr 2925, 2939, 3410; Cz. Lasota, M. Karst, Kościót klarysek $w$ Gtogowie, „Szkice Legnickie” 14, 1992, 9, s. 9-15; O.M. Przybyłowicz, Pro remedio anime? Fundacja klarysek w Gtogowie, „Śląski Kwartalnik Historyczny Sobótka” 2009, t. 64, z. 4, s. 655-684.

25 Urkundensammlung zur Geschichte des Ursprungs der Städte und der Einführung und Verbreitung Deutscher Kolonisten und Rechte in Schlesien und der Ober-Lausitz, ed. G.A. Tschoppe, G.A. Stenzel, Hamburg 1832, s. 239; Archiwum Państwowe we Wrocławiu (dalej: APWr), Rep. 91, nr 567.

${ }^{26}$ RS, CDS, Bd. 18, ed. C. Grünhagen, K. Wutke, Breslau 1898, nr 4191; CDS, Bd. 28, s. 65, 105, 161. Obecność sołtysów w miastach jest nadal słabo rozpoznana. Na tym tle wyróżniają się badania dla Poznania (J. Wiesiołowski, Szlachta w mieście, s. 54) i Świdnicy (M. Goliński, Wokót socjotopografii, cz. 2, s. 152-154). 
Przyjmuje się, że książęcy kwartał (stanowiący aż 1/3 powierzchni miasta), na którym stanęły powyżej wymienione obiekty, miał swoją kontynuację w późnośredniowiecznym „lennie zamkowym” - obszarze wyłączonym spod jurysdykcji władz municypalnych ${ }^{27}$. Tymczasem teren przynależny do zamku wzmiankowano od 1360 roku (początkowo jako das burg firteil, a w kolejnym wieku jako Burglehn, Schloß-und Burglehnsfreiheit i Burgfreiheit). Dowodnie „lenno” obejmowało wówczas zachodni pas ziemi, północny był zaś w rękach Kościoła ${ }^{28}$. Większość Burglehn prawnie scalono z miastem dopiero w epoce nowożytnej, choć już od połowy XV wieku jego fragmenty pozyskiwały władze municypalne ${ }^{29}$. W 1480 roku głogowscy rajcy otrzymali od księcia fragment „żydowskiego placu”, na którym stał już miejski kierat $^{30}$ (ryc. 1.9). W tym czasie gminę żydowską przeniesiono w sąsiedztwo klasztoru Bernardynów, czyli na zachód od zamku, a rajcy wykupili fragment terenu przy Judengasse ${ }^{31}$. W 1525 roku miasto pozyskało obszar za kościołem Dominikanów (z wyjątkiem „domku” dawnego przeora), który sięgał aż po ślady alten Parchen ${ }^{32}$. Najdłużej utrzymano „eksterytorialność”

${ }^{27}$ M. Kutzner, op. cit., s. 166-167; T. Kozaczewski, op. cit., s. 140-144; R. Eysymontt, Kod genetyczny miasta. Średniowieczne miasta lokacyjne Dolnego Ślaska na tle urbanistyki europejskiej, Wrocław 2009, s. 298.

${ }^{28}$ Lehns und Besitzurkunden Schlesiens und seiner einzelnen Fürstenthümer im Mittelalter (dalej: LuBS), t. 1, ed. C. Grünhagen, H. Markgraf, Osnabrück 1965, s. 173; CDS, Bd. 28, s. 81-82, 124, 148, 231. Zagadnienie „zamkowego lenna” w mieście i kompetencji starosty-burgrabiego nie zostało dostatecznie naświetlone w literaturze, a niniejszy tekst nie pretenduje do roli wypełnienia tej luki (o problemie: D. Nowakowski, op. cit., s. 201-204, tam starsza literatura).

${ }^{29}$ F. Minsberg, op. cit., s. 118. Stosunkowo późne przejmowanie przez rajców „zamkowej ziemi” zaobserwowano też i w innych śląskich miastach: jeleniogórską uzyskali w 1475 r., strzelińską - dopiero po 1548 r.: M. Haisig, Pod bertem Korony Czeskiej (1392-1526), [w:] Jelenia Góra. Zarys rozwoju miasta, red. Z. Kwaśny, Wrocław-Warszawa-Kraków-Gdańsk-Łodź 1989, s. 43; K. Drescher, Chronik der Stadt Strehlen, Strehlen 1889, s. 455.

${ }^{30}$ CDS, Bd. 28, s. 127, 128. Koński młyn znajdował się więc przy skrzyżowaniu Paulergasse i Judengasse.

31 Ibidem, s. 82 (w 1440 r. ul. Żydowska była w połowie opuszczona), s. 130-131; F. Minsberg, op. cit., t. 1, Glogau 1853, s. 325, 454-455.

${ }^{32}$ CDS, Bd. 28, s. 161. 
położonego tu Tschammerhof, choć nie bez sprzeciwu rajców ${ }^{33}$. W XVI wieku rada przejęła też część północnego pasa nadrzecznego. Już od początku XIV wieku tuż przy głogowskich obwałowaniach (prope plancas / apud plancas circa valvam) funkcjonowała murowana łaźnia, a działka za nią stała się przedmiotem sporu między kanonikami kolegiackimi a władzami miasta ${ }^{34}$. W 1440 roku obiekt przeznaczono na kąpiele dla ubogich, a w kilkadziesiąt lat później rajcy wykupili od franciszkanów przyległy doń teren ${ }^{35}$.

\section{Domy na „zamkowym lennie”}

$\mathrm{Na}$ terenie zamkowego kwartału można lokalizować dwa domy Rechenbergów ze Sławy, które wcześniej należały do Ebersbachów (ryc. 1 c-d). W 1478 roku Małgorzata Cylejska - księżna-wdowa po Włodku cieszyńskim - nadała je braciom Hansowi i Mikołajowi Ebersbach z prawem dziedziczenia. Przynależne do posesji przywileje (zwolnienie z czynszów i obciążeń miejskich, niższe i wyższe sądownictwo książęce) wzorowane były na wcześniejszej decyzji zmarłego w 1460 roku księcia Włodka i były konsekwencją położenia nieruchomości na Burglehn ${ }^{36}$. Pierwszy z domów stał na parceli zwanej końskim młynem, przy klasztorze Dominikanów („Haus und Hof, das man die Roßmole nennet, bei den schwarzen Mönchen [...] gelegen") ${ }^{37}$. Niedzielni bracia otrzymali też od księżnej przynależne do nieruchomości ogrody i przyległości. Drugi z dworów wzmiankowano jeszcze w 1506 i 1525 roku jako sąsiadujący z dobrami dominikanów (za kościołem) i położony obok działki po nieistniejącej już łaźni wójtowskiej. Stał on tuż przy śladach „starych obwarowań” ${ }^{38}$ i obok domu niejakiego

33 Ibidem, s. 266.

${ }^{34}$ RS, CDS, Bd. 16, nr 3062; Bd. 18, nr 3777, 3783; CDS, Bd. 28, s. 65. W 1425 r. łaźnię wskazano jako opuszczoną.

35 CDS, Bd. 28, s. 83, 160.

36 Ibidem, s. 123-124, 146.

37 Ibidem, s. 123. A zatem dom stał przy pl. Żydowskim (zob. przyp. 30).

$38 \mathrm{~W}$ pierwszej poł. XV w. miasto otrzymało drugi obwód fortyfikacji. Należy zwrócić uwagę na zagadkowy przebieg krótkiego odcinka murów widoczny na planie sprzed 1630 r. i z poł. XVIII w. (ryc. 1, 4). 
Schwarzhansa - dawnego przełożonego klasztoru ${ }^{39}$. Obie posesje zakupili od Ebersbachów bracia Hans i Mikołaj Rechenbergowie (przed rokiem 1480). Obie też w 1509 roku sprzedali głogowskim rajcom, czego naturalnym następstwem było objęcie ich miejskim prawem ${ }^{40}$.

Kolejny dom, zwany od XVI wieku Tschammerhof, to pierwotna baszta zaadaptowana na cele mieszkalne (ryc. 1 a). Zwana była górną basztą i wydaje się tożsama z wymienionym w 1439 roku Weighaus an den Planken, przy murowanej łaźni (tj. wójtowskiej). W tym roku część tego domu otrzymała Dorota Warrichinne ${ }^{41}$, a wcześniej posesję zajmował Michał Messersmed $^{42}$. Od lat sześćdziesiątych XV wieku dwór posiadali kolejno: starosta Bernard Przimke i sędzia czudu Bernard Arnsdorf ${ }^{43}$. To zapewne właśnie w tej baszcie - wówczas w posiadaniu byłego już starosty Przimkego, w obawie przed atakiem Jana Żagańskiego - zabezpieczono w 1480 roku broń z ratusza oraz dobytek Małgorzaty Cylejskiej i mieszczan, który pierwotnie zdeponowano na zamku ${ }^{44}$. Dom Przimkego jednak splądrowano; ucierpiało też kilka dworów patrycjuszowskich ${ }^{45}$. Kasper Borgeni budynek ten rozróżnił od wieży koło zagadkowego Wilnatz, która stała się drugim adresem rozśrodkowania majątku ${ }^{46}$.

O nieruchomości ponownie czytamy w 1505 roku. Z nadania Zygmunta Jagiellończyka zajął ją (po Bernardzie Arnsdorfie) Krzysztof Szydłowiecki, korzystając z przywilejów, którymi cieszyli się w Weighausie jego poprzedni posiadacze. Szydłowiecki i jego spadkobiercy otrzymali posesję z przynależnymi doń prawami: zwolnieniem od czynszów, przywilejami w zakresie prawa budowlanego (w domu i na przyległych murach) oraz drogowego i mostowego, które najpewniej gwarantowały swobodny skład

${ }^{39}$ CDS, Bd. 28, s. 146, 161.

40 Ibidem, s. 146, 148; F. Minsberg, op. cit., t. 2, s. 71.

41 W 1451 r. podkreślono wyjątkową pozycję lub sędziwy wiek Doroty określeniem „matrona”: CDS, Bd. 28, s. 96.

${ }^{42}$ CDS, Bd. 28, s. 80.

${ }^{43}$ Ibidem, s. 231, 265; F. Minsberg, op. cit., t. 2, s. 153-155.

${ }^{44}$ RG, s. 108.

45 Ibidem, s. 110.

46 Wilnatz jako basteję przy farze interpretuje W. Mrozowicz (RG, s. 108), jako dwór wiejski - D. Nowakowski (op. cit., s. 236). 
towaru oraz przejazd na posesję, także przez obszar, na którym obowiązywało miejskie prawo ${ }^{47}$. Korzyściami ekonomicznymi objęto również przynależne do domu nieruchomości (stodołę i plac), które były położone przed Bramą Brzostowską. Zagwarantowano wyłączenie domu spod jurysdykcji głogowskich rajców, explicite wszystkich jego mieszkańców: użytkowników i służby, którzy podlegać mieli sądowi gospodarza. On sam zaś, w sprawach osobistych i majątkowych - podlegał bezpośrednio jurysdykcji władcy i jego starosty, a w pozostałych - sądowi mańskiemu, ale z prawem wyboru połowy jego składu ${ }^{48}$. Jeszcze w tym samym roku dwór od Szydłowieckiego uzyskał Ernest Tschammer ${ }^{49}$, z zastrzeżeniem jednak przeznaczenia swojego dotychczasowego domu na „schronienie” dla oficjała ${ }^{50}$.

W piśmiennictwie Tschammerhof utożsamiono z siedzibą wójta Głogowa. Hipoteza Mariana Kutznera była konsekwencją jego dyskusji z Juliusem Blaschke w sprawie lokalizacji łaźni, którą ten pierwszy umiejscowił - zgodnie z przekazem źródeł - przy kościele dominikanów ${ }^{51}$ (ryc. 1.7). Autor przypuszczał, że i dom wójta stał w sąsiedztwie klasztoru i tym samym powiązał go z omawianym dworem. Lokalizacja i pierwotne przeznaczenie posesji wydaje się jednak inne. Była to dawna baszta, która stała niedaleko Bramy Brzostowskiej i jeszcze w XVIII wieku pozostawała w rękach

${ }^{47}$ CDS, Bd. 28, s. 231, 265; F. Minsberg, op. cit., t. 2, s. 153-155 (tu edycja całego dokumentu).

${ }^{48}$ P. Kozák, op. cit., s. 111-112. Autor uznał przywileje za coś niebywałego, ale korelującego z aspiracjami późniejszego posiadacza domu - Ernesta Tschammera. W przeciwieństwie do autora nie jestem przekonana, ani o pałacowej okazałości dworu, ani o wyjątkowości przywilejów, które były konsekwencją przynależności domu do „zamkowego lenna" (por. dom omówiony powyżej). Podzielam jednak jego opinię, że zakres tych korzyści był szczególny; zob. też: F. Matuszkiewicz, Die mittelalterliche Gerichtsverfassung des Fürstentums Glogau, Breslau 1911, s. 74-75.

${ }^{49}$ P. Kozák, op. cit., s. 112. Autor spekuluje, że może od początku Szydłowiecki był de facto tylko „pośrednikiem” transakcji, a docelowym odbiorcą - Ernest Tschammer (o karierze szlachcica zob. P. Kozák, op. cit., s. 90-113, 144-155).

${ }^{50}$ CDS, Bd. 28, s. 231.

${ }^{51}$ M. Kutzner, op. cit., s. 167, 198. Łaźnia zw. wójtowską, a po 1360 r. - królewską, wymieniana jest od k. XIII w. W 1525 r. już nie istniała, a na jej miejscu stanął „biały dom": Urkundensammlung, s. 396-397; CDS, Bd. 28, s. 161. 
szlacheckich ${ }^{52}$. W XIX stuleciu była zajazdem pod „Czarnym Orłem”, na miejscu którego, oraz na działce pozyskanej po zlikwidowaniu umocnień, wzniesiono w 1904 roku nowoczesny hotel Karola Majunke i ponownie nazwano go „Dworem Tschammera” 53 .

Przywołany już drugi dom Tschammerów, expilicite „domek”, położony miał być naprzeciwko pierwszego (ryc. 1 b). Przypuszczalnie to właśnie ów „domek” był rezydencją ochmistrzyń dworu książąt cieszyńskich. Od 1459 roku zajmowała go stara Braunowa (alte Brawnynne) ${ }^{54}$. To zapewne Małgorzata - ochmistrzyni na zamku „cieszyńskim” i żona dworzanina Kaspra Brauna, która weszła w dożywotnie posiadanie dworu z ogrodem, z nadania Włodka i Małgorzaty. W 1459 roku Braunowa dokupiła sąsiedni ogród od wspomnianego już Bernarda Przimke ${ }^{55}$. Po jej śmierci (a przed lutym 1460 roku) książę Włodko nadał dom z kawałkiem placu w dziedziczne posiadanie staroście Konradowi Tschammer, a ten musiał go wynająć kolejnej ochmistrzyni - z rodziny Kelbichen. W 1478 roku mieszkała w nim bowiem młoda Kelbichenowa (die junge Kelbchenynne) ${ }^{56}$, a Konrad przekazał dom synowi - Ernestowi ${ }^{57}$. Tenże w 1478 roku uzyskał dodatkowo od władczyni plac na „zamkowym lennie” (jego użytkownikiem był wcześniej Zygmunt Stößel - starosta części „głogowskiej”) ${ }^{58}$, a w 1483 roku wykupił od Anny - wdowy po Zygmuncie oraz jej synów - kolejny fragment Burglehn ${ }^{59}$. W 1499 roku przejął zaś od Jana Unwürde ziemię położoną za zamkiem (za murami miasta, czyli na zachód od warowni). Ogród ten kupili niegdyś Baltazar i Hans Uwnwürde od Jadwigi Pentzke, a jego wieloletnim użytkownikiem był Baltazar z Rzeczycy ${ }^{60}$. s. 111).

${ }^{2}$ CDS, Bd. 28, s. 266. Tego dworu nie pozyskali rajcy (inaczej: P. Kozák, op. cit.,

53 CDS, Bd. 28, s. 231; J. Blaschke, op. cit., s. 165.

${ }^{54}$ CDS, Bd. 24, s. 77.

55 Ibidem, s. 75, 77.

56 Ibidem, s. 77.

${ }^{57}$ CDS, Bd. 28, s. 231.

58 Ibidem, s. 119, 231; F. Minsberg, op. cit., t. 2, s. 523.

${ }^{59}$ CDS, Bd. 24, s. 78.

${ }^{60}$ APWr, Rep. 132 d. Depozyt von Ziebern, nr 529 (11), nr 531 (13); CDS, Bd. 28, s. 265. 
Na terenie cmentarza dominikanów (przy samym końcu Melczgasse / Słodowej) znajdowała się jeszcze jedna nieruchomość szlachecka (ryc. 1 e). Przed 1459 rokiem była ona w posiadaniu najprawdopodobniej rodziny Krökwitz, choć de facto wiemy tylko o Creckewitczynne Garten ${ }^{61}$. W 1465 roku wymieniono tam dwór panny Barbary z Wandritschów, który przeznaczono na przyklasztorny szpital. Na zakonników przeszły także przypisane do adresu zwolnienia od miejskiego czynszu i obowiązków komunalnych (Wache, Bede, Scharwerk). W 1509 roku to właśnie tę placówkę uposażył Melchior Krökwitz z Krzepielowa ${ }^{62}$.

\section{Domy u północnej części miasta}

W nadrzecznej części miasta, gdzie - jak wspomniano - książę ufundował klasztor franciszkanów i dom klarysek, wskazać możemy dwa domy szlacheckie. Jeden to wymieniony w 1463 roku dwór pani lub panny Kottwitz (Kottewitczynne), który położony był naprzeciwko klarysek i warsztatu sukiennika $^{63}$ (ryc. 1 f). Drugi to nieruchomość Krzysztofa von Kottwitz, wymieniona w 1524 roku, jako położona przy „wielce ubogich” ogrodach franciszkanów (ryc. $1 \mathrm{~g}$ ). Ogrody te sięgały od szlacheckiej posesji po zewnętrzny pas fortyfikacji (Parchen) i tamtejszą furtę ${ }^{64}$. Oba dwory zatem musiały znajdować się w pobliżu biskupiej posesji ${ }^{65}$ (ryc. 1.3; 2).

Niejasne jest, czy miejski dom ordynariusza można powiązać z dworem wymienionym już przed rokiem $1238^{66}$. W literaturze identyfikowano go z folwarkiem w pobliskiej wsi Kamiona ${ }^{67}$. Józef Domański przekonywał zaś, że to przedlokacyjne osiedle, które wchłonięte zostało przez miasto,

${ }^{61}$ CDS, Bd. 24, s. 75.

${ }^{62}$ CDS, Bd. 28, s. 111, 149.

${ }^{63}$ Ibidem, s. 109.

${ }^{64}$ Ibidem, s. 160.

65 Zob. Urkundensammlung, s. 239.

${ }^{66}$ Liber Fundationis Claustri Sancte Marie Virginis in Heinrichow, czyli Ksiega Henrykowska, wyd. R. Grodecki, Wrocław 1991, s. 196.

${ }^{67} \mathrm{~Np}$. Stownik etymologiczny nazw geograficznych Śląka, red. H. Borek, Warszawa-Wrocław 1988, s. 136. 
zwane było Cameniza, za czym przemawiać miał - jego zdaniem - zapis z 1253 roku i informacja o nadrzecznym młynie ${ }^{68}$. Warto odnotować, że na początku XVI stulecia wymieniono młyn biskupa położony powyżej Harnischmole ${ }^{69}$, czyli nad rzeczką Sępolno, w kierunku Ruszowic. W tej podmiejskiej wsi biskup posiadał ogród ${ }^{70}$.

\section{Domy przy kamiennej drodze}

Ostatnie, niewielkie skupisko domów, położone było na Ostrowie Tumskim, przy Steinweg i znamy je dopiero z wieku XVI. Dwory były położone za murami miasta, w znacznym oddaleniu od Rynku, przy szlaku w kierunku Wielkopolski. Kamienna droga to bowiem trasa naśladująca przebieg jeszcze przedlokacyjnego ciągu przeprawowego przez Odrę, pierwszy raz wymieniona w 1333 roku $^{71}$. W północnej części wyspy znajdowała się kolegiata i domy kanoników. Z części południowej wydzielono w 1337 roku miejską jurydykę ${ }^{72}$ (ryc. 3). Wiadomo, że to tam stały, przynajmniej od połowy XV wieku, rezydencje głogowskich patrycjuszy ${ }^{73}$. Przez wyspę prowadziły do mostu jeszcze dwie mniejsze drogi: Wagenweg i kleine Steinweg (zob. ryc. 3), obok których (tj. przy granicy obszaru miejskiego i kolegiackiego)

${ }^{68}$ SUb, Bd. 3, nr 102; J. Domański (rec.), Śląskie studia toponomastyczne, cz.1, S. Rospond, Wroctaw 1959, „Onomastica” 13, 1968, 1-2, s. 283; zob też.: SUb, Bd. 4, ed. W. Irgang, Köln-Wien 1988, nr 289 (curia seu allodium nostrum episcopale, quod Kamenza wlgariter nuncupatur); Liber fundationis episcopatus Vratislaviensis, ed. H. Markgraf, J.W. Schulte, CDS, Bd. 14, Breslau 1889, E 209 (unum allodium de V mansis, quod Camenicza appellatur). Zagadnienie to wymaga pogłębionych badań, gdyż może być ważne dla rozważań o początkach miasta. Nie znalazło jednak rozwinięcia w omówieniu biskupich rezydencji pióra E. Wółkiewicz Curia episcopalis. Organizacja rezydencji biskupów wroctawskich w późnym średniowieczu, [w:] Dom, majątek, klient, stuga. Manifestacja pozycji elit w przestrzeni materialnej i spotecznej, red. R.M. Pauk, M. Saczyńska, Warszawa 2010, s. 93-94.

${ }^{69} \mathrm{CDS}, \mathrm{Bd} .28$, s. 152.

70 Ibidem, s. 81 .

${ }^{71}$ RS, CDS, Bd. 22, ed. C. Grünhagen, K. Wutke, Breslau 1903, nr 5238; także: CDS, Bd. 28, s. 44, 88, 109.

${ }^{72}$ RS, Bd. 29, ed. K. Wutke, Breslau 1922, nr 5861; M. Kutzner, op. cit., s. 189.

${ }^{73}$ CDS, Bd. 28, s. 88, 167. 
stały domy szlachty, choć wiemy tylko o tych w posiadaniu Kottwitzów i Stibitzów. Dalej w kierunku rzeki rozciągały się ogrody i mieszczańskie składy $^{74}$.

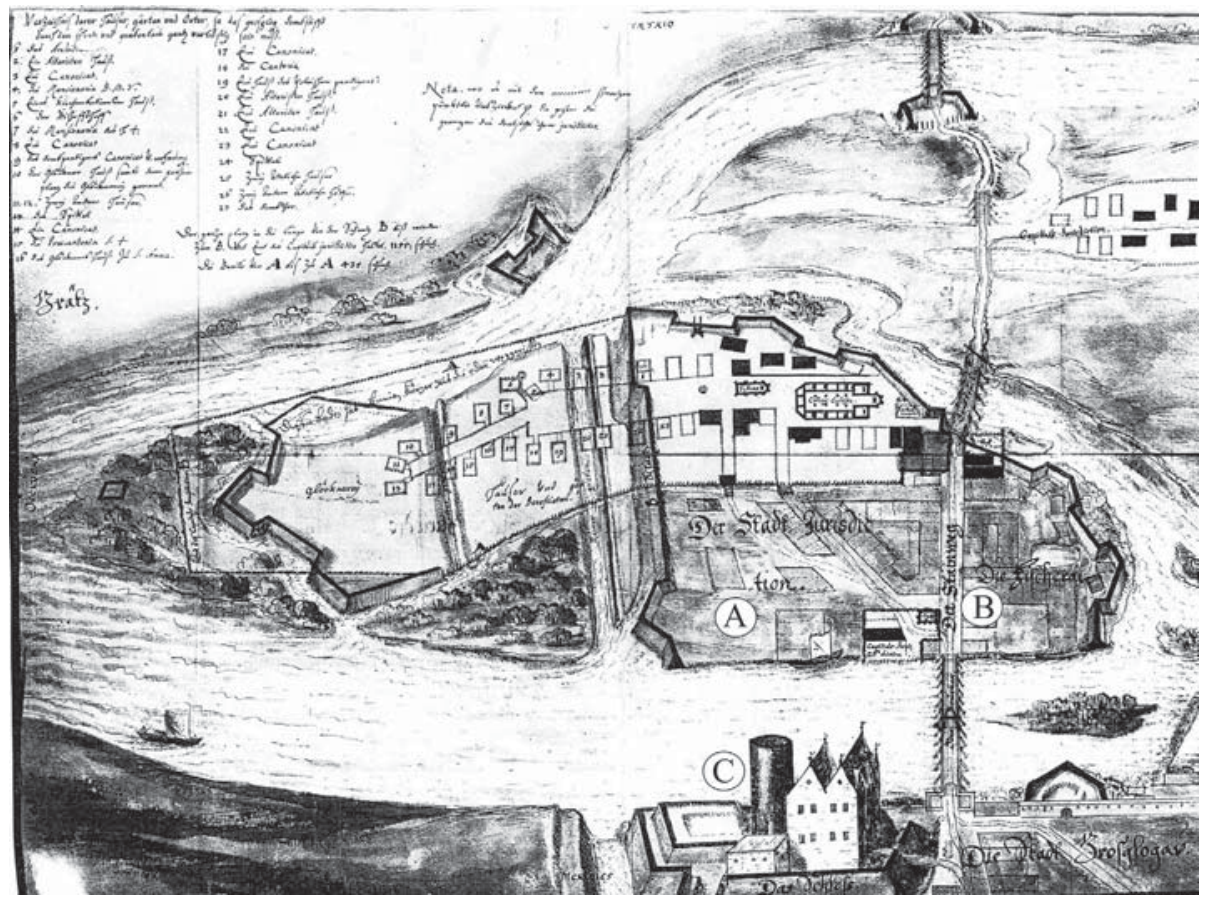

Ryc. 3. Fragment lewobrzeżnego miasta i Ostrowa Tumskiego w 1635 roku

A - miejska jurydyka (Der Stadt Jurisdiction); B - osada rybacka (Die Fischeräi) i kamienna droga (Die Steinweg); C - zamek (Das Schloss)

Źródło: Archiwum Państwowe we Wrocławiu, Wydział Samorządowy Prowincji Śląskiej, sygn. 688.

Dom Hansa Kottwitza wymieniono w 1540 roku, kiedy stanowił punkt odniesienia w sporze między głogowską radą a kanonikami kolegiaty o grunt położony przy „dużej kamiennej drodze”. Ostatecznie plac zlokalizowany naprzeciwko domu Kottwitza - między „drogą dla wozów” a „małą kamienną drogą" - mogło wykorzystać miasto. Obok dworu Kottwitza wy-

${ }^{74}$ Ibidem, s. 88, 103, 106, 137, 168. 
mieniono dom Melchiora Stibitza, którego ogrody bezprawnie zajmowały parkany (postawione zapewne na granicy jurydyki miejskiej i kościelnej, por. ryc. 3$)^{75}$.

\section{Funkcje i charakter nieruchomości}

Domy na Burglehn związane były ze „światem zamku”. Choć rolę naturalnej siedziby urzędników i dworzan spełniała warownia, to w XV stuleciu przekazywano im pobliskie domy (w dożywocie, a w kolejnych latach w dziedziczenie). Zamek był zrujnowany i wymagał remontu na pewno już na początku XVI stulecia. W momencie przejęcia go przez Zygmunta Jagiellończyka

trzeba było (...) dbać przede wszystkiem o to, żeby dach nie zaciekał i deszcz komnat nie zalewał (...). Mieszkalnych komnat w obszernym, nadrujnowanym zamku snadź było niewiele, skoro dostojni goście, przybywający z daleka, w mieście szukali przytułku ${ }^{76}$.

Usprawiedliwia to przekaz, że to jeden z głogowskich domów stał się stancją Krzysztofa Szydłowieckiego, który przybył wraz z władcą ${ }^{77}$. W 1505 roku oficjał sprzedał nieruchomość Tschammerom, ale zachował prawo do używania ich dotychczasowego domu jako zajezdnego ${ }^{78}$.

Szlacheckie dwory poznajemy dopiero w schyłkowym okresie podziału miasta na część królewską i książęcą. „Kwartał zamkowy” pozostał w czę-

75 Ibidem, s. 167.

${ }^{76}$ A. Pawiński, Mtode lata Zygmunta Starego, Warszawa 1893, s. 160, 270; D. Nowakowski, op. cit., s. 220.

77 O Szydłowieckim zob.: P. Kozák, op. cit., passim (tam starsza literatura); Idem, Dvorská spolećnost hlohovského a opavského vévody Zikmunda Jagellonského, [w:] Dvory a rezidence ve stredověku. II. Skladba a kultura dvorské společnosti, ed. D. Dvořáčková-Malá, J. Zelenka, Praha 2008, s. 262-263; zob. też: Mezi periferii a centrem jagellonského světa: Registrum dvoŕanů knižete a krále Zikmunda I. Jagellonského z let 1493-1510, ed. P. Kozák, K. Rábai, Opava 2015, s. 8, 9, 61, 131, 197.

${ }^{78}$ CDS, Bd. 28, s. 231; Bd. 24, s. 80. 
ści Luksemburgów, którą nadano władcom cieszyńskim ${ }^{79}$. W tej sytuacji, po 1404 roku, Piastowie głogowscy wznieśli nową siedzibę przy Bramie Szpitalnej (ryc. $1 \mathrm{~B})^{80}$. Już w 1480 roku zaniedbaną rezydencję wykupili rajcy ${ }^{81}$. Mimo funkcjonowania w mieście dwóch zamków, szlacheckie posesje odnotowano tylko pod warownią „cieszyńską”. W części „głogowskiej” zatem to zamek musiał pełnić rolę domu noclegowego dla dworzan i urzędników ${ }^{82}$.

Niewykluczone, że domy na „zamkowym lennie” mają metrykę starszą od wzmiankowanej. Najbardziej prawdopodobne wydaje się (co sugeruje też rysunek Fryderyka Bernarda Wernera, ryc. 4), że przyzamkowe siedziby powstały jako konsekwencja adaptacji na mieszkania fortyfikacji oraz zabudowy sąsiadujących z nimi działek, co miało miejsce w śląskich miastach w ciągu XIV stulecia.

Zachowane źródła mogą dawać wrażenie, że - analogicznie do Torunia - mamy w Głogowie do czynienia z późnym pozyskiwaniem przez szlachtę miejskich nieruchomości ${ }^{83}$. W dokumencie podziałowym z 1360 roku nie wymieniono bowiem jeszcze żadnej posesji rycerskiej, a wyszczególniono sporo adresów mieszczańskich, w tym kamienne domy - wyróżniające się na tle drewnianej zabudowy Głogowa ${ }^{84}$. Nawet jeżeli jako

${ }^{79}$ Głogów był w latach 1360-1481 podzielony na dwie gminy. Zachodnia była pod władzą Luksemburgów, a od 1384 r. ich lenników - książąt cieszyńskich; wschodnia - Piastów głogowskich: LuBS, s. 172-178, 192-193, 196-198; CDS, Bd. 28, s. 35; H. Szczegóła, Koniec panowania piastowskiego nad środkową Odrą, Poznań 1968, s. 113-115. Następstwem linii podziału było nie tylko ustalenie przynależności do gmin poszczególnych ulic i budynków, ale i wytworzenie odrębnych organów władzy komunalnej: M. Słoń, op. cit., s. 361-370; Idem, Jak gtogowscy rajcy stawali przed Bogiem. Przyczynek do religijności komunalnej późnego średniowiecza, [w:] Lustro. Teksty o kulturze średniowiecza ofiarowane Halinie Manikowskiej, red. W. Brojer, Warszawa 2013, s. 219-220.

${ }^{80}$ CDS, Bd. 28, s. 44; D. Nowakowski, op. cit., s. 341-342.

${ }^{81}$ CDS, Bd. 28, s. 126; F. Minsberg, op. cit., t. 1, s. 450-451. Ostatni książęta głogowscy rezydowali w Kożuchowie.

${ }^{82}$ Przypomnę jednak, że Zygmunt Stößel posiadał nieruchomość w części „cieszyńskiej”.

${ }^{83}$ K. Mikulski, op. cit., s. 129-130.

${ }^{84}$ LuBS, s. 172-178. Zakaz krycia słomą wydany został dla części „cieszyńskiej” po pożarze miasta w 1420 r.: F. Minsberg, op. cit., t. 1, s. 416. 


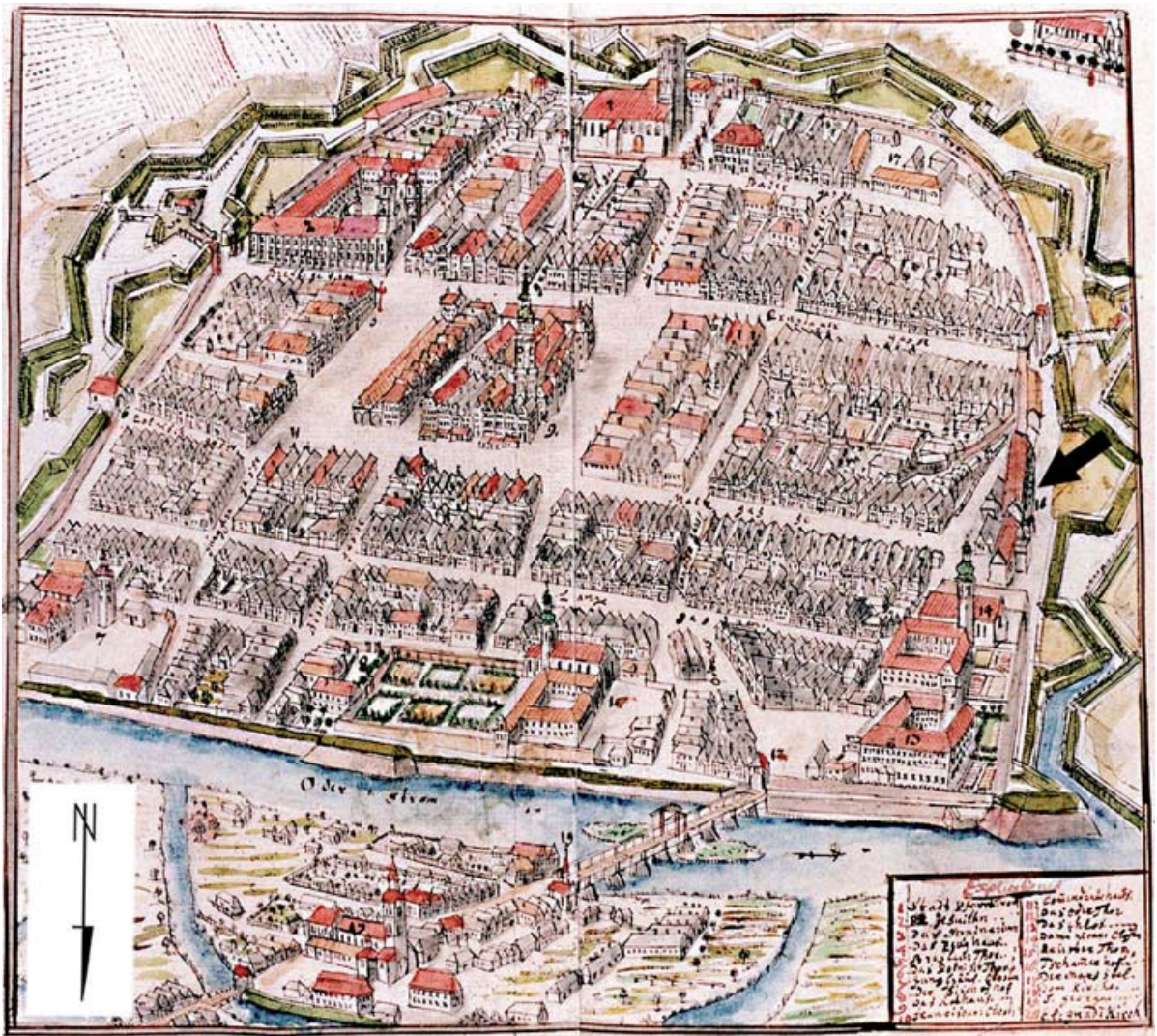

Ryc. 4. Widok miasta w połowie XVIII w. według Fryderyka Bernarda Wernera $\mathrm{z}$ widocznym domem Tschammerów

Źródło: Biblioteka Uniwersytecka we Wrocławiu, Dział Kartografii, F. B. Werner, Topographia Silesiae, Bd. 5, domena publiczna.

miejską posesję rycerza odczytamy murowany dwór ze słodownią Andrzeja von Berge z 1453 roku $^{85}$, to w dokumencie podziałowym prawdopodobnie ten sam obiekt zaadresowano jeszcze jako umocniony dom mieszczanina Hanka Schwartzena ${ }^{86}$.

${ }^{85}$ Położony przy ulicy prowadzącej do furty św. Jana, obok fary: CDS, Bd. 28, s. 99.

${ }^{86}$ LuBS, s. 173. 
Powody utrzymania przez szlachciców posesji w Głogowie można w świetle dotychczasowej literatury sprowadzić do kilku hipotez ${ }^{87}$. Te na Burglehn pełniły funkcję domów stałych lub periodycznych, zwłaszcza w sytuacji konieczności przebywania w mieście przez dłuższy czas ${ }^{88}$. Były one w posiadaniu starostów, urzędników sądowych oraz dworzan. Położenie nieruchomości opodal Bramy Brzostowskiej sugeruje także możliwość traktowania ich jako centrum miejskich interesów gospodarczych. Wszak głogowscy rycerze byli także posiadaczami dóbr wiejskich (tabela 1). W skład działki Tschammerów wchodziła stodoła, co można odczytać jako ślad składowania zboża ${ }^{89}$. Zapewnienie domom (Freihäuser) zwolnienia od czynszów i ciężarów miejskich mogło dawać szlachcicom możliwość czerpania dochodów z przełamania gospodarczych monopoli miasta (w XVII wieku wodę dla Tschammerhofu czerpano jednak z bardzo odległej studni przy jezuickim gimnazjum $)^{90}$.

Odmienny wydaje się charakter domów obok szlaku handlowego, w sąsiedztwie nieruchomości mieszczańskich. Przypuszczam, że były to rezydencje szlachciców, którzy swoje życie związali z miastem na stałe. Tak

87 Dom rycerski jako gospodarczo-handlowe centrum dóbr, czasowa i stała siedziba, sposób na lokatę kapitału i zabezpieczenie kredytu, manifestacja pozycji społecznej oraz szerzej - problem karier rycerzy w miastach przedstawili ostatnio: T. Zotz, Adel in der Stadt des deutschen Spätmittelalters. Erscheinungsformen und Verhaltensweisen, "Zeitschrift für Geschichte des Obberheins" 141 (Neue Folge 102), 1993, s. 22-50; A. Ranft, Stadt und Adel im späten Mittelalter. Ihr Verhältnis am Beispiel der Adelsgesellschaften, [w:] Die Kraichgauer Ritterschaft in der frühen Neuzeit, ed. S. Rhein, Sigmaringen 1993, s. 47-63; A. Mindermann, Adel in der Stadt des Spätmittelalters: Göttingen und Stade 1300 bis 1600, Bielfeld 1996; M. Hecht, Städtisches „Patriziat“ und regionaler Adel, [w:] Die Stadt im Raum. Vorstellungen, Entwürfe und Gestaltungen im Vormodernen Europe, ed. K. Igel, T. Lau, Köln-Weimar-Wien 2016, s. 111-130.

${ }^{88}$ Wskazani szlachcice to $\mathrm{w}$ większości zaangażowana politycznie elita, zwana przez P. Kozáka (Zrod stavovského, passim) „liderami miejskiej gminy”.

${ }^{89} \mathrm{~W} 1486 \mathrm{r}$. Tschammerowie weszli w posiadanie pobliskiej wsi i folwarku Kamiona: APWr, Rep. 132 d. Depozyt Ziebern, nr 524 (6), 527 (9); CDS, Bd. 28, s. 264.

${ }^{90}$ CDS, Bd. 28, s. 266. O gospodarczej funkcji dworów klasztornych, które przyrównuje się z rycerskimi, pisał m.in. W. Schich, Topographische Lage und Funktion zisterziensischer Stadthöfe im Mittelalter, [w:] Der Adel in der Stadt des Mittelalters und der frühen Neuzeit (Materialien zur Kunst und Kulturgeschichte in Nord- und Westdeutschland 25) Marburg 1996, s. 279-294, a także: A. Malczewska, Posesjonaci szlacheccy, s. 118-120. 
można wnioskować po lekturze anonimowej pieśni pochwalnej na cześć Głogowa ${ }^{91}$. Poeta wyszczególnił jeden zespół dworów w kwartale zamkowym, gdzie według niego stało ich wiele. Część była nowo wzniesiona, a część już opuszczona ${ }^{92}$. Drugie skupisko zauważył on jednak przy kamiennej drodze. Tam znajdować się miały domy zajmowane przez szlachciców oraz ich żony i dzieciin.

Pisarz nie odnotował natomiast żadnych domów szlacheckich w sąsiedztwie biskupiego pałacu, co może sugerować, że w połowie XVI wieku nie istniało jakieś wyraźne ich skupisko. Dwór pani lub panny Kotwitz mógł być „domem dusznym”, położonym w pobliżu klasztoru klarysek. Pojedyncza informacja o dworze jej współrodowca (sędziego czudu), nie pozwala zaś na spekulacje, choć lokalizacja posesji w tej prestiżowej części miasta nie wydaje się przypadkowa.

Analiza rozłożenia dóbr szlacheckich posesjonatów wykazuje pewną prawidłowość. Wszyscy oni posiadali majątki we władztwie

${ }^{91}$ Pieśń powstała na wzór starożytnych, naśladowanych w całej renesansowej Europie, np.: J. Serczyk, Krzysztof Falk (okoto 1520-1572), kronikarz i literat elblaski, [w]: Zastużeni ludzie dawnego Elblaga, red. M. Biskup, Wrocław 1987, s. 41-43; Nikolaus Thomas, Pieśń pochwalna o mieście Świdnicy, wyd. S. Nowotny, Świdnica 1997. Twórca rymowanej laudacji głogowskiej opisał miasto z jego przedmieściami jako centrum przestrzeni, do której prowadziły znaczące drogi, i która było areną ważnych wydarzeń z przeszłości. Zleceniodawcami utworu byli prawdopodobnie rajcy, którym autor poświęcił kilka strof. Wiadomo tylko, że utwór pochodzi z poł. XVI w., i że sporządził go raczej głogowianin, który dysponował znajomością dokumentów oraz wiedzą na temat zaułków miasta. Autograf był przechowywany w bibliotece franciszkańskiej w Głogowie. Jego druk został przygotowany w poł. XIX w. i - według mojej oceny - jedynie on zachował się do naszych czasów: Lobspruch der Stadt Glogau zum ersten Male nach einer Handschrift aus dem 16. Jahrhundert, ed. F.W. von Raczek, Glogau 1865.

92 Lobspruch der Stadt, s. 11:

Findet man zunächst am hindern ort

Etliche viel Hofe und Heuser allein

Zum teil aufs neu aufgerichtet fein, so die von Adel bewohnen und ihnen Han

ein teil auch wüste und ledig stan.

93 Ibidem, s. 12:

In welchem den ihr Wohnung han

Etliche von Adel mit Weib und Kind. 
głogowskim ${ }^{94}$. Dobra wiejskie w $80 \%$ położone były w promieniu $35 \mathrm{~km}$ od miasta, z czego $40 \%$ do $20 \mathrm{~km}$, a $60 \%$ w przedziale $21-35 \mathrm{~km}$ (tabela 1). Zbliżone zjawisko zauważono w przywoływanej Świdnicy. W tamtejszej grupie rycerskich posesjonatów znaleźli się dworzanie książęcy i urzędnicy pełniący funkcje sądownicze - posiadacze podmiejskich dóbr (w $90 \%$ do ok. $35 \mathrm{~km}$ od miasta) ${ }^{95}$. Utrzymywali oni jednocześnie siedziby wiejskie, z którymi związek podkreślali w swoich tytulaturach.

Tabela 1. Posiadacze nieruchomości i ich wiejskie dobra

\begin{tabular}{|c|c|c|c|}
\hline Posiadacz & $\begin{array}{l}\text { Zajmowane } \\
\text { stanowisko }\end{array}$ & Wiejskie dobra & $\begin{array}{l}\text { Wiejska } \\
\text { siedziba }\end{array}$ \\
\hline $\begin{array}{l}\text { Hans i Mikołaj } \\
\text { Ebersbach }\end{array}$ & sędziowie dworscy & Kromolin, Mirocin, Szczepów & $\begin{array}{l}\text { Kromolin, } \\
\text { Mirocin }\end{array}$ \\
\hline $\begin{array}{l}\text { Małgorzata Braun } \\
\text { (żona Kaspra) }\end{array}$ & ochmistrzyni & $\begin{array}{l}\text { Drogomil, Grodziec Mały, } \\
\text { Lubogoszcz, Osetno, Przecław, } \\
\text { Solniki, Witanowice }\end{array}$ & $\begin{array}{l}\text { Witanowice, } \\
\text { Solniki }\end{array}$ \\
\hline $\begin{array}{l}\text { (Barbara?) Kelbichen } \\
\text { (żona Reinczkego?) }\end{array}$ & ochmistrzyni? & Kłoda? & \\
\hline Bernard Przimke & starosta & Gostyń, Kłoda & Gostyń \\
\hline Bernard Arnsdorf & sędzia czudu & Gostyń & Gostyń \\
\hline Konrad Tschammer & starosta & $\begin{array}{c}\text { Komorniki, Kotla, Merzdorf (ob. } \\
\text { cz. Starego Strącza), Osetno, Osetno } \\
\text { Małe, Równa }\end{array}$ & Osetno \\
\hline Ernest Tschammer & $\begin{array}{l}\text { starosta ziemski, } \\
\text { z-ca starosty }\end{array}$ & $\begin{array}{l}\text { Kamiona, Kietlów, Kotla, Komorniki, } \\
\text { Merzdorf, Niwa, Orzeszków, Osetno, } \\
\text { Rejów, Równa }\end{array}$ & Osetno \\
\hline $\begin{array}{l}\text { Mikołaj i Hans } \\
\text { Rechenberg }\end{array}$ & sędziowie dworscy & $\begin{array}{l}\text { Lubogoszcz, Merzdorf, Otyń, Radzyń, } \\
\text { Sława, Stare Strącze }\end{array}$ & $\begin{array}{c}\text { Sława (miast- } \\
\text { eczko) }\end{array}$ \\
\hline Zygmunt Stößel & $\begin{array}{c}\text { starosta } \\
\text { (cz. „głogowskiej”) }\end{array}$ & Tarnów Bycki & \\
\hline Krzysztof Kottwitz & sędzia czudu & Grodziec Mały & $\begin{array}{l}\text { Grodziec } \\
\text { Mały }\end{array}$ \\
\hline
\end{tabular}

${ }^{94}$ Por. ustalenia J. Wiesiołowskiego (Szlachta w mieście, s. 53-55).

${ }^{95}$ M. Goliński, Rycerstwo w mieście, s. 165-167, 171; Idem, Wokót socjotopografii, cz. 2, s. $146-152$. 
Kilkudziesięcioletnie badania archeologiczne w Głogowie - jedne z najszerzej zakrojonych na terenie Polski, które objęły około 50 ha $^{96}$ - dawały szansę na podjęcie kwestii manifestacji pozycji społecznej szlachty poprzez ostentację miejskich nieruchomości ${ }^{97}$. Zakres prac na interesujących nas kwartałach nie jest jednak zadowalający. W wypadku części „lenna zamkowego" założono jedynie długi wykop sondażowy. Ujawniono fragmenty dawnych obwarowań, dwie studnie oraz „zarys średniowiecznych domów”. Zespół Tadeusza Kozaczewskiego nie kontynuował badań, a wyników nie analizował, uznając je za nietrafione, gdyż ich celem było odnalezienie kościoła dominikanów ${ }^{98}$. Na północy, pomiędzy klasztorem klarysek a franciszkanów, rozpoznano natomiast relikty średniowiecznego domu z okrągłą klatką schodową. Nietypowość tego założenia daje nadzieję, że odkryto ślady po dworze biskupa. Relikty zaś pobliskich domów nie odbiegały niczym od zabudowy miejskich posesji ${ }^{99}$.

\section{Podsumowanie}

Udało się wyróżnić trzy skupiska dworów w Głogowie: teren „zamkowego lenna”; północne obrzeża miasta oraz obszar miejskiej jurydyki na Ostrowie Tumskim, przy kamiennej drodze. Adresy pięciu domów należy umieścić w bliskim sąsiedztwie zachodnich fortyfikacji. Jeden z nich odczytać możemy wręcz jako Weighaus, czyli basztę w obrębie murów miejskich, przystosowaną do celów mieszkalnych. O przyległości umocnień zaświadcza też nadane prawo budowlane, które dotyczyć miało prac „przy i na murach miejskich”. Jeden z domów Rechenbergów stał obok śladów po „starym obwarowaniu”. Na planie miasta, wykonanym przed 1630 rokiem, wi-

${ }^{96}$ Zob. M. Chorowska, Parcelacja Gtogowa na tle lokacji miejskich na Ślasku, [w:] Glogovia maior. Wielki Gtogów między blaskiem dziejów i cieniem ruin, red. B. Czechowicz, M. Konopnicka, Głogów-Zielona Góra 2010, s. 123-138 (tam starsza literatura).

${ }_{97}$ Por. wnioski dla Krakowa P. Węcowskiego (op. cit., s. 53) i odmienne dla Świdnicy M. Golińskiego (Wokót socjotopografii, cz. 2, s. 145-146).

98 T. Kozaczewski, op. cit., s. 89.

$99 \mathrm{Za}$ prezentację niepublikowanych wyników badań archeologicznych dziękuję dr. Krzysztofowi Czapli. 
doczne są w tym miejscu nie tylko co najmniej trzy wolnostojące budynki równolegle ułożone do dominikańskiego kościoła, ale także obiekty przyległe do miejskich murów ${ }^{100}$. Domom towarzyszyły stodoła, place i ogrody, które zostały wyznaczone na niewielkiej działce, skoro zajmowały teren tuż pod fortyfikacjami lub (i) w międzymurzu ${ }^{101}$. Metryka owych dworów nie jest jasna. Poznajemy je dopiero w połowie XV wieku i możemy jedynie domniemywać o ich starszej genezie. Za panowania książąt cieszyńskich Włodka i Małgorzaty - kwartał zamkowy był już w części objęty miejską jurydyką. Znajdującym się nań domom zapewniono jednak „eksterytorialność”, czyli utrzymano enklawę ekscypowaną spod jurysdykcji władz municypalnych. Ostatecznie jednak większość wspomnianych posesji przejęło miasto ${ }^{102}$. Jedynie można wskazać dwa domy poza murami miejskimi i oba dowodnie stały tam w połowie XVI stulecia; kolejne dwa - w sąsiedztwie posesji mieszczańskich, ale w prestiżowej części miasta, gdzie znajdowała się parcela biskupa oraz klasztory.

Utrzymywanie przez szlachciców miejskich posesji w większości wypadków koreluje z pełnieniem przez nich funkcji dworskich i urzędniczych, ale jednocześnie z posiadaniem majątków wiejskich. Dwory na „zamkowym lennie” mogły zarówno pełnić rolę domów noclegowych, jak i dawać ich posiadaczom możliwość realizacji interesów gospodarczych, czemu sprzyjało położenie posesji przy miejskiej bramie. W przypadku nieruchomości na Ostrowie Tumskim hipoteza o stałej obecności szlachciców w mieście wydaje się prawdopodobniejsza.

${ }^{100}$ W. Klawitter, Geschichte der schlesischen Festungen in vorpreußischer Zeit (Darstellung und Quellen zur schlesischen Geschichte 39) Breslau 1941, il. 3.

${ }^{101}$ Ogrody pod murami zostały oznaczone kamiennymi krzyżami (CDS, Bd. 28, s. 231).

$102 \mathrm{Z}$ analogicznym zjawiskiem „wolnych domów” mamy do czynienia też w innych miastach Śląska oraz na terenie Kłodzka: Regesten Saganer Lehnbriefe vor 1510, ed. G. Steller, Kiev 1942, nr 116, 190, 206, 275; A. Malczewska, Posesjonaci z rodu, s. 208. 